\title{
Behavioral Causes of the Bullwhip Effect: Multinational vs. Local Supermarket Retailers
}

\author{
Himanshu Shee \\ College of Business, Victoria University \\ Melbourne, Australia \\ Email: Himanshu.Shee@vu.edu.au (Corresponding Author) \\ Surahman Kaswi \\ Politeknik Negeri Samarinda, Indonesia \\ Email: surahman@polnes.ac.id
}

\begin{abstract}
Managers' perception of extra days of product ordering characterises behavioral causes of the bullwhip effect that is not yet addressed so far in literature. The study therefore investigates and compares behavioral causes of the bullwhip effect within- and between multinational and local supermarkets in a three-echelon retail chain. Retail chain stock replenishment practices embodied in a survey was distributed to managers of supplier firms, wholesale distribution centres and small retail stores in Indonesia. The data was analysed using ANOVA and post-hoc test. Results show a significant mean difference in extra days of ordering for both MSCs and LSCs. The small retail stores' perceived extra days of ordering are significantly more than what the supplier firms order upstream. Wholesale DC of both chains experiences no such effect. The study helps managers to deepen their understanding of extra days of ordering practice that is likely to be influenced by human behavior leading to the very bullwhip effect. Further, realising its negative impact on the chain performance, they need to carefully orchestrate their extra ordering practices.
\end{abstract}

Keywords: behavioral cause, bullwhip effect, Indonesia, local supply chain, multinational supply chain, retail

\section{INTRODUCTION}

Amplification of demand variation in a supply chain is known as the bullwhip effect (BWE) (Lee, Padmanabhan \& Whang, 1997). Literature nevertheless reveals the operational causes of the bullwhip effect such as demand signalling (i.e. incorrect demand forecasting), order batching, price discount, rationing and shortage gaming etc. (Lee et al., 1997; Dooley et al., 2010). Recent studies by Croson, Donohue, Katok \& Sterman (2014) and Bruccoleri, Cannella \& La Porta (2014) further reveal that human behavior plays significant role in decision making in a chain (Bendoly, Donohue \& Schultz, 2006). The cognitive thinking/behaviour of managers is termed as behavioral causes in this study. Human behavior and cognitive factors very likely affect the business (Gino \& Pisano, 2008). Cognitive behavior, as defined in dictionary, is the mental action or process of acquiring knowledge and understanding through perception, intuition and senses. Lack of trust among partners, incentive misalignment, nonwillingness to share information, overconfidence and biasness, inability to see holistic view and risk aversion are the causes behind the cognitive behavior (Bruccoleri et al., 2014 citing Lee et al., 1997).

This study is an extension of our understanding of the behavioral causes of the bullwhip effect in context of retail supply chain. While earlier scholars have identified decision making agents' action and behavior behind the bullwhip effect, it needs further investigation specifically in a situation of stock ordering. The most recent study using analytical modelling reveals the effect of human behavior on the bullwhip effect (Bruccoleri et al., 2014; Croson et al., 2014). Bruccoleri et al. (2014) assert that workers' behavior (e.g. work pressure and inventory inaccuracies) ultimately causes the bullwhip effect. Croson et al. (2014) argue that individual's decision in a chain (i.e. coordination risk) causes the bullwhip. In a similar logic, we instead argue that managers' intrinsic tendency in the form of 'extra days of order' while replenishing stock is a likely cause, which is novel in this study. We define the 'extra days of order' as the additional stock amount being added up on top of the incoming orders received from downstream partner while ordering up to upstream partner. Managers believe the extra ordering practice is beneficial to meeting higher service level, reducing stock-out situation and stimulating customer demand. We believe however that the human tendency of extra ordering is another cause of the bullwhip effect.

So far demand amplification along retail supply chain focused on case study data recommending further management and improvement of the bullwhip effect (Taylor, 2000; Taylor \& Fearne, 2006, 2009). But no research as yet investigated multinational as compared to local supermarket chain in context of retailing. Local supermarket is a large, one-stop shop that procures from local suppliers and sells grocery, food products and other non-grocery items to local retail stores. The associated supply chain (supplier-wholesale DC- retail store) will be referred to as local supermarket chains (LSC). In contrast, multinational supermarket chain refers to a larger retailer that originates from other country but deems to procure and sale food and general merchandise to local retail stores. This chain is referred to as a multinational supermarket chain (MSC). With the opening up of Indonesia's trade and internationalisation of operations, retailers from 
France (Carrefour), South Korea (Lotte Mart) and Malaysia (Giant) have made their foray into its retail markets. These multinationals are believed to operate and manage the inventories with their standard operating strategies and practices better than local retailers such as Matahari, Indomaret, and Alfamaret. This raises a question considering the stock ordering practices whether MSC's extra days stock ordering practices / (behavior) differ from those of LSC. The paper focuses in specific on the extra ordering behavior of managers/owners of these three-echelon supply chains to see how the bullwhip effect is induced as a result of their actions. It aims to compare the extent of order variability occurs between LSC and MSC which is not yet studied. The paper identifies a number of gaps in the body of literature. First, an analysis of managers' perceptions in stock ordering decision as a systematic error (e.g. at each nodal point) appears to be a missing study in literature. Investigation of managers' cognitive behavior and overconfidence bias in replenishment practice is novel. Second, cross-sectional empirical study on 'extra days of ordering' behavior of the bullwhip effect is rare in supermarket's perishable, semi- and non-perishable product categories. Third, it investigates the existence of the BWE in supermarket chain operations, and explores whether MSC differs from that of LSC in Indonesian context.

This paper, therefore, aims to undertake a cross-sectional study in a three-echelon multinational and local supply chain in Indonesia context to understand the extent to which the managers' ordering behavior affects the bullwhip effect. To verify its effect in supermarkets, three product types are chosen and categorised as perishable, semi-perishable and non-perishable based on their respective shelf-life (e.g. <3 months, 3-12 months and > 12 months). Next section reviews earlier literature with a special focus on behavioral issues. The methodology section explains the survey instrument and measures, data collection, analysis rational and results with hypotheses testing. Finally, the findings are discussed and conclusions are drawn with implications and limitations of the study.

\section{LITERATURE REVIEW}

The bullwhip effect (BWE) is a phenomenon in which demand information is amplified for the upstream suppliers sitting further away from the downstream customers. The generally accepted measurement of bullwhip effect is its index (Torres and Maltz, 2010). The bullwhip effect index is measured by output (variance of upstream order) to input (variance of incoming demand) ratio where mean and standard deviation of an order quantity of a single or a group of products can be used (Nielsen, 2013; Chen et al., 2000). An amplification of the variability is the bullwhip effect. The amplification may dampen $(\mathrm{BWE}<1)$, stay neutral $(\mathrm{BWE}=1)$ or amplify (BWE>1) along the chain. The amplification of the demand information (i.e. the BWE) was then identified and coined by Lee et al. (1997) in a number of retailer-distributormanufacturer chains of consumer goods using DYNAMO simulation model. This was followed by many analytical and simulated experimental studies to identify and measure the bullwhip. This paper however considers behavioral aspects of the effect. Simulated experiment such as the Beer Game (Sterman, 1989; Coppini et al., 2010) reveals managerial behavior and misperception of feedback in a chain. However, the behavioral causes of the BWE using survey based empirical study are not yet documented.

Uncertainty is a major source of the BWE and managers' intervention causes the variances (McCullen \& Towill, 2002; Di Mauro \& Maffioletti, 2004). On the demand side from the downstream customer, managers are uncertain about the quantities (i.e. how many) and timing (i.e. when customers buy). On the supply side from upstream supplier, they are uncertain about supplies and the lead time specifically from the overseas suppliers (Colyle, Gibson, Novack, \& Bardi, 2008). Taylor $(1999,2000)$ argues that variability at the supplier level (i.e. uncertainty in production quantities) is the root cause of the BWE. In the absence of accurate demand estimation, the supplier ends up with higher production quantities partly because of sustaining the scale economy, order batching and capacitated production run (Simchi-Levi et al., 2000).

Prior research so far has analysed the bullwhip effect by employing optimisation (Geary et al., 2006; Ma, Wang, Che, Huang \& Xu, 2013), simulation (Forrester 1958, 1961; Towill \& McCullen, 1999; Paik \& Bagchi, 2007; Klug, 2013; Croson et al., 2014), analytical modelling (Cachon, 1999; Kelle \& Milne, 1999; Chen et al., 2000; Machuca \& Barajas, 2004; Ma et al., 2013; Bruccoleri et al., 2014), and genetic algorithms (O’Donnell et al., 2006; Lu et al., 2012). However, a survey-based empirical study capturing the behavioral dimensions is rarely documented so far in literature. Only exception is the panel data used by some authors (Taylor 1999, 2000; Bray \& Mendelson, 2012; Li \& Lee, 2012; Zotteri, 2013; Shan et al., 2014). Gino and Pisano (2008) assert that 'a behavioral perspective has largely been absent in the field of operations/ inventory management' (p.676).

\section{Stock Ordering Behaviour, Product Types and Bullwhip Effect}

Managers and co-workers are at the centre of decision biases when facing uncertainty in managing various operations. The judgemental heuristics and social circumstances may play a crucial role in the decision biases. Behavioral operations management (BOM) explicitly deals with social and cognitive psychology in this context (Gino \& Pisano, 2008). Literature so far has seen so many research advancing the body of knowledge on BOM (Bendoly et al., 2006; Gino and Pisano, 2008; Bendoly et al., 2010). In this paper we look into managerial intervention that is rooted in the theory of behavioral operations management. While replenishing inventory, the ordering behaviour of managers refers to the way judgement and decisions they take influenced by cognitive thinking rather than much holistic consideration (i.e. chain-wide knowledge). Behavioral issues are more likely to affect the inventory management, procurement and strategic sourcing in supply chain (Bendoly et al., 2006). Bendoly et al., (2010) explain human 
(managers') behavior as relating to individual decision making (e.g. cognitive psychology) and group dynamics through interaction (e.g. social psychology), and claim that, in either case, overconfidence in forecasting, underestimating the variability, anchoring on irrelevant past observations and experiences leading to biasness in stock replenishment. Donohue and Siemsen (2011) supported this in their study. We looked into the behavioral aspects using cognitive thinking while ordering upstream in context of a three-echelon retail chain.

Managers are always limited with information processing ability grounded in the theory of bounded rationality (Simon, 1979). Simon (1979) asserts that managers do suffer from bounded rationality as they are unaware of omniscience, meaning "largely unaware of all the alternatives, uncertainty about exogenous events, and inability to calculate consequences (p.502)". This decision-making approach results from the fact that each individual acts on the basis of what is known to him/her, i.e. mutual knowledge (Croson et al., 2014). Croson et al., (2014) posit further that decision output using mutual knowledge is likely to worse off than under 'common knowledge' where each individual knows what others along the chain also know about it. The perception of individual respondents captured through a survey method in a three-echelon chain can simulate the individual decision making situation that seems to cause the bullwhip in this research. The effect will be high when an individual manger is unaware of how the other partner manager will behave.

Behavioral causes of the bullwhip effect are also studied earlier using the Beer Distribution Game. Sterman (1989) observed channel partners' irrational behaviour (random action), inability of a holistic view, and time delays in information sharing as the main causes. The BWE is attributed to chain partners' non-willingness to share demand information (Evans, Naim, \& Towill,1993; Taylor \& Fearne, 2009). Chatfield et al. (2004) assert that attitude to share quality information may likely to reduce 50 per cent variance amplification. An investigation of ordering behavior of retail store managers reveals that managers intervene in order quantity decision when they operate under uncertainty (Ancarani et al., 2013), and care less about reducing inventory because the handling capacity constraint outweighs carrying cost associated with on-the-shelf extra inventories (Van Donselaar et al., 2010). Nienhaus et al. (2002) argue that with 'safe harbour' strategy managers do order more than actually needed and in a 'panic' they end up with a stock-out situation. While the former leads to high carrying cost, the latter incurs stock-out cost. However, Croson et al. (2014) argue that manager' strategic intervention results in coordination stock to buffer the system against strategic uncertainty that improves performance.

Robertson $(2006,2010)$ classifies supermarket food and non-food products into three categories: perishable (very short shelf-life), semi-perishable (short to medium shelf-life), and non-perishable (medium to long shelf-life products). Perishable foods are kept at freezer room with temperature between $0^{0} \mathrm{~F}\left(-18^{0} \mathrm{C}\right)$ to $7^{0} \mathrm{~F}\left(-14^{0} \mathrm{C}\right)$ and $12^{0} \mathrm{~F}\left(-11^{0} \mathrm{C}\right)$ to $18^{0} \mathrm{~F}$ $\left(-8^{0} \mathrm{C}\right)$ respectively. In this study, both semi-perishable and non-perishable food products are considered as shelf-life between 3-12 months and more than 12 months respectively. Classification of non-food products is based on the type of merchandise sold, mostly represented in sectors-44 and 45 (Levy \& Weitz, 2012). These non-food products mostly have shelf-life more than 12 months long life sold in supermarket (Levy and Weitz, 2012; NAICS, 2012).

This study, therefore, considers products being classified as shelf-life less than 3 months (i.e. perishable), 3-12 months (i.e. semi-perishable) and more than 12 months (i.e. nonperishable) respectively. The decision on extra days of ordering while replenishing these products is inevitably associated with their shelf lives. Merchandise with lesser shelf-life will have less extra days of order than products with more shelf-life. This extra days of ordering varies across these products, so is associated with retailers' order to wholesale DCs, and then to suppliers. Further, we hypothesise that this would likely to vary between MNC and local chain. In view of this, we propose the following three hypotheses: first (H1) is for MNC chain; second (H2) is for local chain; and third (H3) compares ordering practices between two chains.

H1: For the product categories with varying shelf-life (e.g. $<3$, 3-12 and >12 months), the extra days of ordering varies significantly across retail stores, wholesale DCs and suppliers in MSC.

$\boldsymbol{H} 2$ : For the product categories with varying shelf-life (e.g. $<3$, 3-12 and >12 months), the extra days of ordering varies significantly across retail stores, wholesale DCs and suppliers in LSC.

H3: Extra days of ordering vary significantly between MSC and LSC.

\section{METHODOLOGY}

\subsection{Survey Instruments and Measures}

The study used existing measures based on literature review. Only a three-item questionnaire on ordering practices was adapted from the most cited sources such as Van der Vorst (2000) and Hsiao (2006). This essentially measures managers' extra days of ordering practices in respect to products with varying perishability. The questionnaire items were measured on a five-point Likert scales, 1 being 'strongly disagree' to 5 being the 'strongly agree'. The choice of 5point scales was considered appropriate for eliciting the levels of agreement of managers' perception. Prior to data collection, the survey was pretested with five peer researchers and five supply chains executives from industry. They checked the questionnaire for readability, ambiguity and content appropriateness. The feedback received resulted in minor changes to questionnaire items relating to level of agreement. The final version incorporated these feedbacks which yielded a survey instrument that was judged to exhibit high content validity. 


\subsection{Data Collection}

Indonesian local supermarkets are mostly dominated by three leading players namely local-1, local-2 and local-3 (names are hidden for privacy reason) having 82 stores with three DCs, 5000 stores with 15 DCs, and 6585 stores with 19 DCs respectively (Data Riset Indonesia, 2011). These were conveniently chosen from cities like Jakarta, Bandung and Surabaya with total sample of 15 stores representing local-1 with 8 stores, local-2 with 2 stores and local-3 with 5 stores (Table 1). Further, three multinational (MNC) supermarkets were also conveniently chosen from the same cities. MNC-1, MNC-2 and MNC-3 have 83, 19 and 42 stores respectively spread over these cities. Of these MNC supermarkets operating in Jakarta, Bandung and Surabaya, a total of 26 stores were sampled conveniently with 9 stores for MNC-1, 10 stores for MNC-2, and 7 stores for MNC-3 (Table 1). Therefore, the study sample was comprised of total 41 supermarkets. Further, 51 domestic SME suppliers and 72 retail stores having a trade relationship to the above supermarkets were chosen for the study. The 51 suppliers represent total 13 industry groups with food being $25.49 \%$, cosmetics $15.69 \%$, electronic products $13.73 \%$ and so on (Table 1). They supply perishable, semi-perishable and nonperishable products with varying degree of shelf-life.

Table 1 Distribution of Respondent Firms in the Supply Chain

\begin{tabular}{|c|c|c|c|c|c|}
\hline No & Companies & Characteristics & Count & Column N\% & Owner \\
\hline 1 & Suppliers & $\begin{array}{l}\text { Food industry } \\
\text { Soft drink } \\
\text { Ice-cream } \\
\text { Seasonal products } \\
\text { Fruit canning } \\
\text { Cosmetics } \\
\text { Dairy products } \\
\text { Water (minerals) } \\
\text { Plastic product } \\
\text { Clothing and garments } \\
\text { Electronic products } \\
\text { Household \& furniture products } \\
\text { Stationary } \\
\quad \text { Total }\end{array}$ & $\begin{array}{r}13 \\
3 \\
2 \\
1 \\
1 \\
8 \\
4 \\
2 \\
2 \\
3 \\
7 \\
3 \\
2 \\
51 \\
\end{array}$ & $\begin{array}{r}25.49 \\
5.88 \\
3.92 \\
1.96 \\
1.96 \\
15.69 \\
7.84 \\
3.92 \\
3.92 \\
5.88 \\
13.73 \\
5.88 \\
3.92 \\
100.00 \\
\end{array}$ & $\begin{array}{c}\text { MNC \& local } \\
\text { MNC \& local } \\
\text { MNC \& local } \\
\text { Local } \\
\text { MNC \& Local } \\
\text { MNC \& local } \\
\text { MNC \& local } \\
\text { Local } \\
\text { Local } \\
\text { Local } \\
\text { MNC \& local } \\
\text { MNC \& local } \\
\text { Local }\end{array}$ \\
\hline 2 & Wholesale DCs & $\begin{array}{l}\text { MNC-1 } \\
\text { MNC-2 } \\
\text { MNC-3 } \\
\text { Subtotal } \\
\text { Local-1 } \\
\text { Local-2 } \\
\text { Local-3 } \\
\text { Subtotal } \\
\text { Total } \\
\end{array}$ & $\begin{array}{r}9 \\
10 \\
7 \\
26 \\
8 \\
2 \\
5 \\
15 \\
41\end{array}$ & $\begin{array}{r}- \\
21.95 \\
24.39 \\
17.07 \\
63.41 \\
19.51 \\
4.88 \\
12.20 \\
36.59 \\
100.00 \\
\end{array}$ & $\begin{array}{l}\text { MNC } \\
\text { MNC } \\
\text { MNC } \\
\text { Local } \\
\text { Local } \\
\text { Local }\end{array}$ \\
\hline 3 & Retail Stores & $\begin{array}{l}\text { Retail Store-1 } \\
\text { Retail Store-2 } \\
\text { Retail Store-3 } \\
\quad \text { Total }\end{array}$ & $\begin{array}{r}5 \\
12 \\
55 \\
72\end{array}$ & $\begin{array}{r}- \\
6.94 \\
16.67 \\
76.39 \\
100.00\end{array}$ & $\begin{array}{l}\text { Local } \\
\text { Local } \\
\text { Local }\end{array}$ \\
\hline
\end{tabular}

Thus the sampling frame comprised of 41 wholesale DC/supermarket, 51 suppliers and 72 retail stores representing 41 chains (i.e. for both MSC and LSC) in this study. This paper considers the 'supply chain' as the unit of analysis. It indicates one or more wholesale DCs who procure from more than one supplier and sale out to more than one retail store. The sample distribution of suppliers, DCs and retail stores in Jakarta, Bandung, and Surabaya is presented in Table 2.

Following Huber and Power's (1985) guidelines on how to get quality data from key informants, a survey was undertaken using Dillman's (1978) procedure and administered to supply chain professionals of local and MNC wholesale DCs, their suppliers and retail store in Indonesia
(Table 2). The survey was initiated at wholesale DC level before moved to suppliers and small stores. A total of 450 questionnaires were distributed to respondents across the above cities. A total of 164 completed responses were returned (i.e. 51 suppliers, 41 wholesale DCs and 72 retail stores) resulting in a response rate of 36 per cent which is above the response rates used in literature.

To assess the degree of non-response bias, we compared the responses of early and late waves of returned survey with an assumption that late respondents represent the opinions of non-respondents (Armstrong \& Overton, 1977). 
Table 2 Sampling Distribution of Suppliers, Wholesale DCs and Retail Stores

\begin{tabular}{|c|c|c|c|c|c|c|}
\hline $\begin{array}{l}N \\
0\end{array}$ & City & $\begin{array}{c}\text { Suppli } \\
\text { er }\end{array}$ & $\begin{array}{l}\text { Wholesale } \\
\text { DC }\end{array}$ & $\begin{array}{l}\text { Retail } \\
\text { Store }\end{array}$ & Total & $\begin{array}{l}\text { Percen- } \\
\text { tage }\end{array}$ \\
\hline 1 & Jakarta & 31 & 20 & 42 & 93 & $57 \%$ \\
\hline 2 & Bandung & 7 & 8 & 10 & 25 & $15 \%$ \\
\hline \multirow[t]{3}{*}{3} & Surabaya & 13 & 13 & 20 & 46 & $28 \%$ \\
\hline & Total & 51 & 41 & 72 & 164 & - \\
\hline & Percentage & $31 \%$ & $25 \%$ & $44 \%$ & - & $100 \%$ \\
\hline
\end{tabular}

An independent sample t-test between the mean responses received in the first wave $(98,60 \%$ responses) and the second wave $(66,40 \%$ responses) did not suggest the first wave significantly different from the second wave. Hence, nonresponse bias was not an issue in the data set.

The executives who responded had titles such as logistics/SC manager (24\%), marketing manager (40\%), and owners of retail stores (34\%); represented $72 \%$ male and $28 \%$ female with varying work experience of 5-10 years (40\%) to 11-15 years (54\%); and mostly had Bachelor degrees $(51 \%)$ (Table 3). The data were collected in May - July 2011.

Table 3 Respondent Demographic Characteristics

\begin{tabular}{|l|l|r|r|r|}
\hline & Categories & Frequency & Per cent & $\begin{array}{c}\text { Cumulative Per } \\
\text { cent }\end{array}$ \\
\hline \multirow{2}{*}{ Firm_- } & Retail Stores & 72 & 43.9 & 43.9 \\
& Wholesale DCs & 41 & 25.0 & 68.9 \\
& Suppliers & 51 & 31.1 & 100.0 \\
\hline \multirow{5}{*}{ Position } & Logistics/Supply Chain Manager & 39 & 23.8 & 23.8 \\
& Marketing Manager & 65 & 39.6 & 63.4 \\
& Head of Logistics Department & 3 & 1.8 & 65.2 \\
& Head of Marketing & 1 & 6 & 65.9 \\
Gender & Other/Owner of Convenience/retail store & 55 & 33.5 & 100.0 \\
\hline \multirow{5}{*}{ Education } & Male & 117 & 72.0 & 71.3 \\
& Female & 46 & 28.0 & 100.0 \\
\hline \multirow{3}{*}{ Work } & Secondary School and below & 21 & 12.8 & 12.8 \\
Experience & Diploma/Certificate & 29 & 17.7 & 30.5 \\
& Undergraduate & 84 & 51.2 & 81.7 \\
& Master/PhD & 30 & 18.3 & 100.0 \\
\hline & Less than 5 years & 6 & 3.7 & 3.7 \\
& $5-10$ years & 65 & 39.6 & 43.3 \\
& $11-15$ years & 89 & 54.3 & 97.6 \\
& $16-20$ years & 4 & 2.4 & 100.0 \\
\hline \multirow{5}{*}{ Employees } & Less than 100 employees & 86 & 52.4 & 52.4 \\
& $101-500$ employees & 51 & 31.1 & 83.5 \\
& 501-1000 employees & 10 & 6.1 & 89.6 \\
& $1001-3000$ employees & 14 & 8.5 & 98.2 \\
& More than 3000 employees & 3 & 1.8 & 100.0 \\
\hline
\end{tabular}

\subsection{Analytical Procedure and Rationale}

The survey employed in this study is a way of direct collection of managers' perception of their extra days of ordering in retail chains. In fact, managers' responses provided us direct information on their ordering practices that represented order variation (or deviation) at retailer, wholesale DC and supplier level. The partner managers' perception of extra days of ordering was aggregated to its mean value at each level for each product category. We have used these mean responses as the likely demand deviation. The incremental variation (either as dampen or amplification) deems to occur along the chain when the subsequent upstream partner adds extra quantities on top of the incoming order. The cross sectional survey, however, limits us to capture any such deviation (SD) or an increase in variation of the mean demand along the chain. The significant difference in mean values of these deviations, therefore, is estimated through analysis of variance (ANOVA). This indicates whether the extra days of ordering practice by a partner is significantly different from others. Post-hoc analysis showed a pair-wise comparison of mean to determine which specific partner's extra ordering was more than the other.

\subsection{Test of Reliability and Validity}

The questionnaire collected the responses on three product types based on their perishability i.e. $<3$ months, 3-12 months and $>12$ months. This way it was easy and simple to follow three types of products along the chain and the responses on their extra days of ordering. The questionnaire items adapted from reliable literature sources were pre-tested for content validity for its clarity and appropriateness of use. The responses collected from managers/owners having 
considerable experience in logistics, supply chain and marketing are an evidence of high level of reliable and valid source of information. There was no evidence of biasness in their responses as well. The analysis employed ANOVA and post-hoc test as deemed appropriate and valid to investigate any mean difference between managers' extra ordering practices. The use of a simple three-item questionnaire, however, limited other statistical reliability and validity tests.

\subsection{Results of Analysis}

The aggregated mean values (in absolute days) for MSC and LSC are presented in Table 4. Three product categories represent shelf-life less than 3 months, 3-12 months and over 12 months. The values in Table 4 indicate the ordering variation (in days) to the incoming demand from downstream retail stores through to the suppliers. The aggregated mean values represent the respondent managers' perception of extra days of ordering quantities. The demand information and stock ordering process involves one wholesale DC, at least two retail stores and one or two suppliers. Referring to MNC1 supermarket for MSC with < 3 months shelf-life category (Table 4), wholesale DC's extra days ordering was aggregated to 12.67 days, two retail stores' ordering values to 10.65 days, and two suppliers' values to 10.50 days. This explains the extra orders of 10.65, 12.67 and 10.50 days for retail store, wholesale DC and suppliers respectively. Similar explanation is applicable to MNC-2, MNC-3 and Local-1 to Local-3 supermarket chains. The mean values are further aggregated vertically down to represent overall extra days of ordering for each product for two chain types, MSC and LSC.

Table 4 Summary of Extra Days of Inventory Ordering for MSC and LSC (in absolute days) (mean extra days ordering (of inventory) with shelf-life $<3$ months, 3-12 months and $>12$ months)

\begin{tabular}{|c|c|c|c|c|c|c|c|c|c|c|}
\hline \multirow{2}{*}{ No. } & Unit level & \multicolumn{3}{|c|}{ Supplier } & \multicolumn{3}{|c|}{ Wholesale DC } & \multicolumn{3}{|c|}{ Retail store } \\
\hline & $\begin{array}{l}\text { Product } \\
\text { shelf-life-> }\end{array}$ & $\begin{array}{c}<3 \\
\text { months }\end{array}$ & $\begin{array}{c}3-12 \\
\text { months }\end{array}$ & $\begin{array}{c}>12 \\
\text { months }\end{array}$ & $\begin{array}{c}<3 \\
\text { months }\end{array}$ & $\begin{array}{c}3-12 \\
\text { months }\end{array}$ & $\begin{array}{c}>12 \\
\text { months }\end{array}$ & $\begin{array}{c}<3 \\
\text { months }\end{array}$ & $\begin{array}{c}3-12 \\
\text { months }\end{array}$ & $\begin{array}{c}>12 \\
\text { months }\end{array}$ \\
\hline & \multicolumn{10}{|c|}{ MNC Supermarket Chain (MSC) } \\
\hline 1 & MNC-1 & 10.50 & 11.80 & 10.41 & 12.67 & 10.22 & 11.22 & 10.65 & 7.96 & 11.98 \\
\hline 2 & MNC-2 & 11.00 & 9.75 & 10.67 & 9.70 & 10.20 & 8.50 & 10.31 & 9.33 & 9.48 \\
\hline 3 & MNC-3 & 12.64 & 13.71 & 9.07 & 8.71 & 8.00 & 6.57 & 6.57 & 7.29 & 7.17 \\
\hline & Average & 11.38 & 11.75 & 10.05 & 10.36 & 9.47 & 8.76 & 9.18 & 8.19 & 9.54 \\
\hline & \multicolumn{10}{|c|}{ Local supermarket chain (LSC) } \\
\hline 1 & Local-1 & 10.81 & 10.50 & 9.88 & 9.25 & 10.50 & 8.63 & 7.89 & 8.63 & 10.09 \\
\hline 2 & Local-2 & 13.00 & 12.58 & 10.50 & 10.50 & 13.00 & 13.00 & 9.25 & 10.92 & 9.67 \\
\hline 3 & Local-3 & 10.33 & 12.67 & 12.33 & 11.80 & 11.00 & 14.00 & 9.00 & 9.17 & 10.75 \\
\hline & Average & 11.38 & 11.92 & 10.90 & 10.52 & 11.50 & 11.88 & 8.71 & 9.57 & 10.17 \\
\hline
\end{tabular}

Note: The table values represent extra days of ordering which is the deviation (SD) from the mean order.

To ensure whether the extra ordering practices significantly different from one partner to another, we conducted analysis of variance (ANOVA) test. This was followed by post-hoc test to compare who orders for more days than other.

\section{(i) Analysis of variance (ANOVA) for MSC}

We hypothesized (H1) for MSC that for the product categories with varying shelf-life (e.g. <3, 3-12 and >12 months), the extra days ordering varied across retail stores, wholesale DC and suppliers in MSC chain. We split it into the following three sub-hypotheses based shelf-life of three products.
H1a: For the product category $<3$ months shelf-life, the extra days of ordering varies significantly across retail stores, wholesale DC and suppliers.

$\boldsymbol{H} \mathbf{1 b}$ : For the product category 3-12 months shelf-life, the extra days of ordering varies significantly across retail stores, wholesale DC and suppliers.

H1c: For the product category $>12$ months shelf-life, the extra days of ordering varies significantly across retail stores, wholesale DC and suppliers. 
Table 5 Analysis of Variance (ANOVA) for Firm Categories in MSC

\begin{tabular}{|l|l|l|l|l|}
\hline $\begin{array}{c}\text { Product } \\
\text { shelf-life } \\
\text { (months) }\end{array}$ & $\begin{array}{l}\text { Retail } \\
\text { Store }\end{array}$ & Wholesaler & Supplier & $\begin{array}{l}\mathrm{F} \\
\text { statistics }\end{array}$ \\
\hline$<3$ & $4.13^{\mathrm{a}}$ & 3.93 & 3.17 & $9.53^{*}$ \\
\hline $3-12$ & $4.07^{\mathrm{a}}$ & 3.71 & 3.03 & $21.19^{*}$ \\
\hline$>12$ & $4.13^{\mathrm{b}}$ & 3.96 & 3.60 & $5.10^{\star *}$ \\
\hline
\end{tabular}

${ }^{\mathrm{a}}$ Retail store mean is significantly different from supplier at $\mathrm{p}<.001$

${ }^{\mathrm{b}}$ Retail store mean is significantly different from supplier at $\mathrm{p}<.01$

${ }^{*} \mathrm{~F}$ Significant at the $\mathrm{p}<.001 * *$ F Significant at the $\mathrm{p}<.01$

ANOVA test (Table 5) revealed that a significant mean difference occurred between retail stores, wholesale DC and suppliers on product categories $<3$ months (F $(2,120)$, $\mathrm{p}<.001)), 3-12$ months $(\mathrm{F}(2,120), \mathrm{p}<.001))$, and $>12$ months $(\mathrm{F}(2,120), \mathrm{p}<.01))$ shelf-life. Retail stores, wholesale DC and suppliers are likely to add significant extra days of inventory while ordering. Hence sub-hypotheses H1a, H1b and H1c were supported. This result however doesn't confirm whether retailers' extra ordering is more than what wholesale DCs or suppliers do order upstream.

To know who ordered more than other, pair-wise posthoc test (Table 6) results showed that retail stores' extra ordering was significantly more than what the suppliers ordered each product categories upstream. The likely reason is that retail stores' less frequent and batch ordering practices warrant extra days of inventories as opposed to suppliers' frequent ordering of small quantities to its upstream supplier. The extra ordering practices led to access inventory in the MSC pipeline. However, results showed that wholesale DC had no significant difference ( $p>.05)$ with other two. This appears that wholesale DC adds up non-significant quantities on to what it receives from downstream small retailers, thereby experiencing no sign of bullwhip effect.

Table 6 Post-hoc Analysis of Firm Categories in MSC

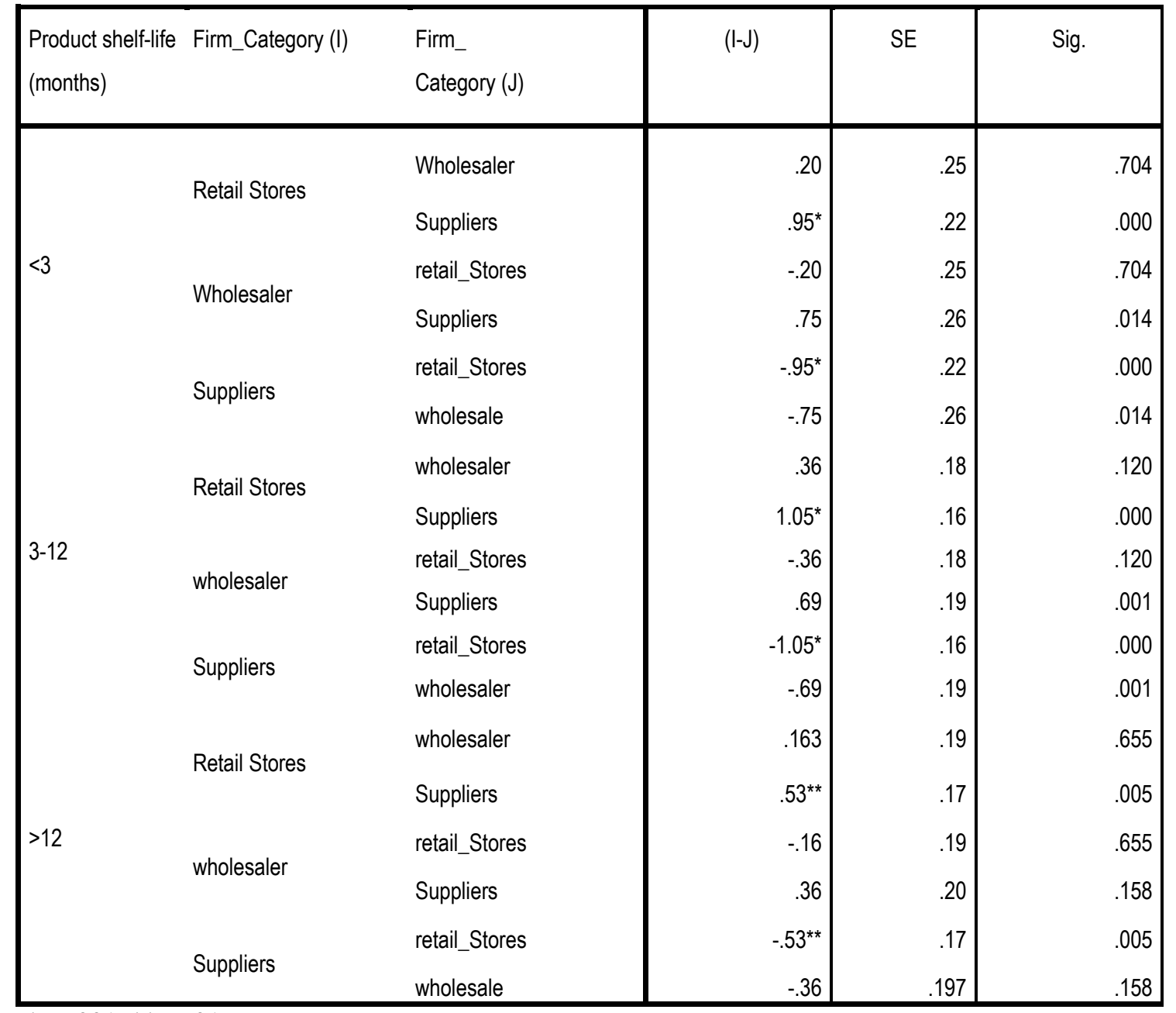

$* \mathrm{P}<.001, * * \mathrm{P}<.01$ 
(ii) Analysis of Variance (ANOVA) for LSC

We hypothesized $(\mathrm{H} 2)$ for LSC that for the product categories with varying shelf-life (e.g. <3, 3-12 and >12 months), the extra days of ordering varied across retail stores, wholesale DC and suppliers in local retail chain. To verify this, we split this hypothesis into following three subhypotheses based on the product shelf-life.

H2a: For the product category $<3$ months shelf-life, the extra days of ordering varies significantly across retail stores, wholesale DC and suppliers.

$\boldsymbol{H} \boldsymbol{2 b}$ : For the product category 3-12 months shelf-life, the extra days of ordering varies significantly across retail stores, wholesale DC and suppliers.

$H 2 \boldsymbol{c}$ : For the product category $>12$ months shelf-life, the extra days of ordering varies significantly across retail stores, wholesale DC and suppliers.

ANOVA test (Table 7) revealed a significant mean difference in extra ordering practices between suppliers, wholesale DC and retailers on product categories $<3$ months (F (2, 76), p<.05), 3-12 months $(\mathrm{F}(2,76), \mathrm{p}<.01)$ and $>12$ months $(\mathrm{F}(2,76), \mathrm{p}<.05)$. Therefore, the hypotheses H2a, $\mathrm{H} 2 \mathrm{~b}$ and $\mathrm{H} 2 \mathrm{c}$ were supported.

Table 7 Analysis of Variance (ANOVA) for Firm Categories in LSC

\begin{tabular}{|c|c|c|c|c|}
\hline $\begin{array}{l}\text { Product } \\
\text { shelf-life } \\
\text { (months) }\end{array}$ & $\begin{array}{l}\text { Retail } \\
\text { Store }\end{array}$ & Wholesaler & Supplier & $\begin{array}{l}\mathrm{F} \\
\text { statistics }\end{array}$ \\
\hline$<3$ & $4.03^{\mathrm{a}}$ & 3.67 & 3.04 & $5.15 *$ \\
\hline $3-12$ & $3.87^{\mathrm{a}}$ & 3.60 & 2.92 & $7.17 *$ \\
\hline$>12$ & $3.67^{b}$ & 3.40 & 3.00 & $5.10 * *$ \\
\hline \multicolumn{5}{|c|}{$\begin{array}{l}{ }^{*} \mathrm{P}<.01, * * \mathrm{P}<.05 \\
{ }^{\mathrm{a}} \text { Retail store mean is significantly different from supplier at } \\
\mathrm{p}<.01 \\
\mathrm{~b} \text { Retail store mean is significantly different from supplier at } \\
\mathrm{p}<.05\end{array}$} \\
\hline
\end{tabular}

Further, a pair-wise comparison results (post-hoc test) (Table 8) revealed a significant mean difference between retail stores and suppliers $(\mathrm{p}<.01)$. However, wholesale DC showed no difference with other two. So the retail stores had significant extra ordering perceived to be more than those of suppliers in relation to the local chain.

Table 8 Post-hoc Analysis of Firm Categories in LSC

\begin{tabular}{|c|c|c|c|c|c|}
\hline $\begin{array}{l}\text { Product } \\
\text { Shelf-life } \\
\text { (months) }\end{array}$ & $\begin{array}{l}\text { Firm_- } \\
\text { Category(l) }\end{array}$ & $\begin{array}{l}\text { Firm_ } \\
\text { Category (J) }\end{array}$ & (I-J) & SE & Sig. \\
\hline \multirow{4}{*}{$<3$} & Retail Stores & $\begin{array}{l}\text { wholesaler } \\
\text { Suppliers }\end{array}$ & $\begin{array}{l}.36 \\
.99 *\end{array}$ & $\begin{array}{l}.36 \\
.31\end{array}$ & $\begin{array}{l}.588 \\
.005\end{array}$ \\
\hline & wholesaler & $\begin{array}{l}\text { retail_Stores } \\
\text { Suppliers }\end{array}$ & $\begin{array}{r}-.36 \\
.63\end{array}$ & $\begin{array}{l}.36 \\
.39\end{array}$ & $\begin{array}{l}.588 \\
.252\end{array}$ \\
\hline & Suppliers & $\begin{array}{l}\text { retail_Stores } \\
\text { wholesaler }\end{array}$ & $\begin{array}{l}-.99^{*} \\
-.63\end{array}$ & $\begin{array}{l}.31 \\
.39\end{array}$ & $\begin{array}{l}.005 \\
.252\end{array}$ \\
\hline & retail Stores & $\begin{array}{l}\text { wholesaler } \\
\text { Suppliers }\end{array}$ & $\begin{array}{l}.27 \\
.95^{\star}\end{array}$ & $\begin{array}{l}.30 \\
.25\end{array}$ & $\begin{array}{l}.637 \\
.001\end{array}$ \\
\hline \multirow[t]{3}{*}{$3-12$} & wholesaler & $\begin{array}{l}\text { retail_Stores } \\
\text { Suppliers }\end{array}$ & $\begin{array}{r}-.27 \\
.68\end{array}$ & $\begin{array}{l}.30 \\
.32\end{array}$ & $\begin{array}{l}.637 \\
.094\end{array}$ \\
\hline & Suppliers & $\begin{array}{l}\text { retail_Stores } \\
\text { wholesaler }\end{array}$ & $\begin{array}{l}-.95^{*} \\
-.68\end{array}$ & $\begin{array}{l}.25 \\
.32\end{array}$ & $\begin{array}{l}.001 \\
.094\end{array}$ \\
\hline & retail Stores & $\begin{array}{l}\text { wholesaler } \\
\text { Suppliers }\end{array}$ & $\begin{array}{r}.27 \\
.67^{\star *}\end{array}$ & $\begin{array}{l}.29 \\
.24\end{array}$ & $\begin{array}{l}.634 \\
.023\end{array}$ \\
\hline \multirow[t]{2}{*}{$>12$} & wholesaler & $\begin{array}{l}\text { retail_Stores } \\
\text { Suppliers }\end{array}$ & $\begin{array}{r}-.27 \\
.40\end{array}$ & $\begin{array}{l}.29 \\
.31\end{array}$ & $\begin{array}{l}.634 \\
.414\end{array}$ \\
\hline & Suppliers & $\begin{array}{l}\text { retail_Stores } \\
\text { wholesaler }\end{array}$ & $\begin{array}{l}-.67^{* *} \\
-.40 \\
\end{array}$ & $\begin{array}{l}.24 \\
.31 \\
\end{array}$ & $\begin{array}{l}.023 \\
.414 \\
\end{array}$ \\
\hline
\end{tabular}

$* \mathrm{P}<.01, * * \mathrm{P}<.05$ 
(iii) ANOVA between MSC vs. LSC

We hypothesized (H3) that MSC and LSC's extra days of ordering varied significantly from each other. The following three sub-hypotheses were formulated.

$\boldsymbol{H 3 a}$ : For product category $<3$ months shelf-life, the extra days of ordering varies significantly between MSC and LSC.

$\boldsymbol{H} 3 \boldsymbol{b}$ : For product category 3-12 months shelf-life, the extra days of ordering varies significantly between MSC and LSC.

H3c: For product category $>12$ months shelf-life, the extra days of ordering varies significantly between MSC and LSC.

ANOVA results showed a significant difference (F $(1,162), \mathrm{p}<.001)$ between MSC and LSC for products with more than 12 months shelf- life (Table 9). Post-hoc analysis results (Table 10) showed MSC's extra ordering perceived to be significantly $(\mathrm{p}<.001)$ more than LSC for products with $>12$ months shelf-life. So the hypothesis H3c was supported but not $\mathrm{H} 3 \mathrm{a}$ and $\mathrm{H} 3 \mathrm{~b}$.

Table 9 Analysis of Variance (ANOVA) between MSC and LSC

\begin{tabular}{|l|l|l|l|}
\hline Shelf-life (months) & MSC & LSC & $\begin{array}{l}\text { F } \\
\text { statistics }\end{array}$ \\
\hline$<3$ & 3.73 & 3.57 & .70 \\
\hline $3-12$ & 3.63 & 3.48 & 1.05 \\
\hline$>12$ & $3.99^{a}$ & 3.25 & $27.26^{*}$ \\
\hline
\end{tabular}

${ }^{a}$ MSC mean is significantly different from LSC at $\mathrm{p}<.001$

*F Significant at the $\mathrm{p}<.001$

Table 10 Post-hoc Analysis between MSC and LSC

\begin{tabular}{|lll|r|r|r|}
\hline $\begin{array}{l}\text { Product } \\
\text { Shelf-life } \\
\text { (months) }\end{array}$ & $\begin{array}{l}\text { (I) Firm_ } \\
\text { Category }\end{array}$ & $\begin{array}{l}\text { (J) Firm_ } \\
\text { Category }\end{array}$ & (I-J) & SE & Sig \\
\hline$<3$ & MSC & LSC & .21 & .19 & .282 \\
& LSC & MSC & -.21 & .19 & .282 \\
$3-12$ & MSC & LSC & .14 & .15 & .345 \\
& LSC & MSC & -.14 & .15 & .345 \\
& MSC & LSC & $.72^{*}$ & $.14^{*}$ & .000 \\
$>12$ & LSC & MSC & $-.72^{*}$ & $.14^{*}$ & .000 \\
\hline$* \mathrm{P}<001$ & \multicolumn{7}{l}{}
\end{tabular}

\section{DISCUSSION}

The paper is set out to understand the chain managers' extra days of ordering practices (behavior) that is likely to cause the bullwhip effect. We investigate as to whether multinational retail chain managers do differ in their stock ordering practices than those of local ones while controlling for the bullwhip effect. An empirical method via survey, therefore, was undertaken to collect chain managers' perceptions on extra days of ordering for merchandise with three different shelf-lives in the multinational and local retail chains in Indonesia. The extra days of inventory ordering by managers is argued here to be a direct measure of demand variability (i.e. standard deviation). The notion of 'adding extra days of order' by each partner on to next partner upstream is believed to have introduced cognitive errors causing the bullwhip effect. The results reveal that both multinational and local chain managers perceive significant extra days of ordering at their level. This could possibly be attributed to the managers' intervention via likely addition of extra days of inventory on top of the incoming ones. They appear to be overconfident in their own decision and opinions (i.e. bounded rationality) as they go on forecasting through past observations and experiences (Gino \& Pisano, 2008). This however results in practices of over-ordering (Bray \& Mendelson, 2012). Let's clarify that the psychological foundations of managers' cognitive thinking is out of scope in this paper.

Demand variation is apparent along the chain, and not necessarily originates from external factors only (Taylor, 1999). We argue the managers' intervention at each nodal point is also a cause of the variation internally. Behavioral issues thus play a key role in causing the effect (Sterman, 1989; Chen et al., 2000; Gino \& Pisano, 2008; Bendoly et al., 2006, 2010). Managers are seen to be continuously changing their order quantities thereby adding to this variability. If they were able to pass on the exact quantities demanded right through the chain to upstream they would get the matching supply with no variability. This practice would ideally result in no bullwhip effect. This tendency of extra ordering puts them into a cycle of misalignment of customer demand versus supply. Results show each partner tends to have extra days of inventory significantly different from each other.

Results supported the hypotheses (H1 to H3) but excluding $\mathrm{H} 3 \mathrm{a}$ and $\mathrm{H} 3 \mathrm{~b}$. Hypotheses $\mathrm{H} 1(\mathrm{a}, \mathrm{b}, \mathrm{c})$ and $\mathrm{H} 2(\mathrm{a}, \mathrm{b}, \mathrm{c})$ offered an overall explanation of how multinational and local firms could experience extra days of stock ordering. This is perceived as the cause of the bullwhip effect. Hypothesis $\mathrm{H} 3 \mathrm{c}$ proved, in specific, MSC's extra days of ordering for products with more than 12 months shelf-life significantly more than LSC. Apparently the long shelf-life products may have some extra days of ordering satisfying the economy of scale. This survey-based empirical study is used first time and serves as an indirect measure of variation (i.e. standard deviation) as estimated in earlier longitudinal studies (Taylor, 1999; Taylor $\&$ Fearne, 2006). We argue this as true evidence of order variation at each nodal point. If we see the bullwhip effect resulting from the extra order while moving upstream (Lee at al., 1997), the argument above is just adequate to suffice it. Further, results show the difference in order variation between partners (i.e. retail stores and suppliers) that leads to the bullwhip effect. However, wholesale DC didn't experience any bullwhip effect in both the chains. The questionnaire though collected very limited information on managers' ordering practices/behavior; some implied information is used from literature to discuss the matter further. 
The results can also be interpreted to explain the causes of the amplification. Order amplification, as explained by Forrester (1958), is primarily a function of decision-making. The decision making is vulnerable to cognitive errors and biasness with serious implications like the case of the BWE. Gino and Pisano (2008) assert that the biasness might affect forecasting, inventory management and supply chain as a whole. The biasness could possibly be anchoring on previous years' sales with a small or inadequate adjustment. Adjustment or errors might originate from managers' tendency of overconfidence and belief (i.e. bounded rationality) that lead to order overestimation subsequently that propagates upstream, a sign of bullwhip effect.

Further, the implicit assumption here is that the approach to extra days of stock seems to be justified as well as beneficial in meeting higher service level, reducing stock-out risk and stimulating demand (Van Donselaar et al., 2010). Further it acts as safety stock or buffer against business uncertainties, and thus depends on how much risk a manager would be willing to afford. While partners' perceived extra order seems buffer against uncertainty, they deem to ignore however the capital cost of carrying inventories that is likely to be overshadowed by other external factors like supplier location, bulk discount and transportation issues. Nonetheless, the carrying cost, as managers believe, is offset by the workload handling cost and the cost associated with the labour requirement to restock shelves (Van Zelst et al., 2009). Thus the very perception of additional ordering of products with more than 12 months shelf-life is an objective approach to fully stocked shelves (Van Donselaar et al., 2010). The extent of extra ordering therefore is always guided by the product perishability. Further, the uncertainty in customer demand (i.e. last minute bulk ordering, order cancellation or any change) tends to allow managers to carry excess inventory, leading to the managerial whim of buffer ordering. The hypotheses testing showed that extra ordering varied significantly across partners. Alternatively, the supply side uncertainty seems to have some influence on buffer stock and demand variability. Discount attached to bulk purchase or any promotional activities from suppliers may trigger managers' behavior to buffer ordering (Taylor \& Fearne, 2009). In either case, the extra days of ordering is triggered by the intent to hold excess days of inventory which is a sign of bullwhip effect.

Stock management is though crucial, it is associated with the behavioral issues. A good amount of learning is disseminated through the Beer Distribution Game and the way it causes the bullwhip (Sterman, 1989; Chen, Drezner, Ryan \& Simchi-Levi, 2000; Lau, 2015). The uncertain characteristics of demand information often drive the partners to rely on their previous period sales experience (Bendoly et al., 2010). Specifically, the mum-and-dad stores, corner-stores and dairy stores, as small retailers, often have neither computerised sales ledger or any hands-on heuristics for next period demand estimation. Further, technological applications remain all time challenge for these small retailers in developing nations (Martín, 2008). With the growing gap of applications in information and communication technology (ICT) between small retailers and suppliers (i.e. wholesale
DCs) in Indonesia, it is plausible that stock management is based on guesswork and owners' perception via simple heuristics or erroneously applied formulae (Tiwari \& Gavirneni, 2007; Gino \& Pisano, 2008). Such a raw estimation results in less likely shortages or stock-out, but leads to a situation of over-stock instead. This is where the retail stores are very likely to work in a buffer-pull (i.e. ordering more) environment.

\section{CONCLUSIONS AND IMPLICATIONS}

This research has identified the very existence of the bullwhip effect (i.e. increase/decrease in demand variability) in multinational and local supply chain in Indonesia. Wholesale DCs of both chains experience no bullwhip effect though. This research partially complements many earlier ones on longitudinal or experimental studies that have had the sign of bullwhip effect in respective contexts. However, 'survey based empirical study' is a novel approach, and has added up a new dimension to the current body of literature. While the earlier studies recognised the causes behind the variability, the managers' extra days of ordering behaviour thus affecting the variability was not been documented yet in retail. The results enable us to conclude that managers' perceived extra ordering practice induced incremental variability resulting in the bullwhip effect.

The research has direct implications on retail chain managers and will draw their attention to the way they respond and add to the inherent variation in demand characteristics (i.e. varying mean and standard deviation). They need to know that the variation further gets affected by their intrinsic behaviours than the extrinsic vulnerability of a firm's position within the chain. The intrinsic behaviour apparently comes from their cognitive biases (i.e. thinking, motivation and emotional process) and rules of thumb which affect the decision makers. While these variations are inherent in supply chain, the three chain partners need to reassess their decision around extra ordering practices in order to get the effect minimum. Chen et al. (2000) assert that demand estimation can act as filter to reduce the effect. For the perishable products (i.e. less than 3 month shelf-life), the extra ordering practice or safety stock can be avoided if the emergency replenishment via local suppliers is a way out to dodge an imminent stock out situation at small retailer level. Further, every order quantity must take into account the perishability or wastage that is usually associated with socalled Newsboy Problem (Silver et al., 1998). Any variation from one period to other can be well managed by short-term weekly forecast that can capture the likely true demand of the next period (i.e. for next week) while adjusting to suppliers' lead time and optimum service level. It should therefore be possible to control the extra ordering practices through a revised ordering policy potentially holding no extra days of ordering.

Managers' perception of the extra days of ordering for semi- and non-perishable (i.e. more than 3 months) products seems to be appropriate given supply and demand uncertainty, 
particularly considering suppliers' (assumed) longer lead time. Although this results in the bullwhip effect, Pujawan \& Silver (2008) posit that augmenting the order quantity under stochastic demand is favourable. The managers, however, must trade-off between ordering cost, product carrying cost for relatively longer shelf-life, labour cost for material handling and shelf refilling, and like. While both the chain partners are free to choose the suppliers from within and outside Indonesia, the extra ordering approach might go well with considerably longer supply replenishment. Results revealed that both the chain managers, therefore, perceived to order more for products with more than 12 months shelf-life. Additionally, transparent and timely sharing of demand information is likely to reduce the current bullwhip effect in both chains (Paik and Bagchi, 2007; Taylor \& Fearne, 2009). Signing up an agreement among the partners is a way out, and must be initiated by the wholesale DCs (of both chains) who appear to strategically leading the business in the chain. Though wholesale DC has experienced no effect of bullwhip, the small retail stores downstream however will have it through extra orders. This can be avoided by collaborative arrangement and application of ICT that will apparently help in the actual demand information flow among the echelons and will likely be free from all forms of distortion.

The study contributes to the continuing bullwhip effect research considering human factor as crucial. With chainversus-chain competition paradigm, managers need to aware of their extra ordering approach as detrimental to chain performance. This study will deepen managers' understanding of human behavior and its associated negative impact thereby attempting to redesign the system and policies to provide accountability for the behavioral issues. The study contributes to the body of demand management literature in a sense that inventory ordering in retail chain is significantly dependent on product shelf lives. It is evidenced that frequent ordering is suitable for products with less than three months shelf-life versus less frequent bulk ordering for products having more than twelve months shelf-life. It extends the understanding of its significance for supermarket retail chains in specific.

The paper involves limitations. On the methodological side, the research setting and cross-sectional survey undertaken among the stakeholders in one country could limit the generalizability of the findings. The descriptive statistics and ANOVA though have a good theoretical support but future longitudinal data along the three echelon supply chain will improve our current understanding of behavioral issues of the bullwhip effect. It must also be noted that a larger questionnaire and sample size in future research will be able to capture more information to increase the statistical power. We believe that interview with the managers would explore more information on their intrinsic actions thereby helping to redesigning the policies. On the theoretical side, further research needs to focus on psychometric characteristics (e.g. cognitive and social character) of managers and change management perspective that could help in minimising the effect. Whilst managers' intrinsic behavioral issues within a chain dominate the extra days ordering decision, quality training, mentoring and team work with focused sociotechnical aspects (Ingvaldsen \& Rolfsen, 2012) would probably a right course of action to pick up the next research agenda.

\section{ACKNOWLEDGEMENT}

We acknowledge out deep gratitude to the editor and anonymous reviewers for their valuable comments to improving the paper. Also we extend out thanks to the respondents from Indonesia who provided their valuable feedback at the time of data collection.

\section{REFERENCES}

Ancarani, A., Di Mauro, C., D’Urso, D., (2013), A human experiment on inventory decisions under supply uncertainty. International Journal of Production Economics 142(1), pp. 6173.

Bray, RL. and Mendelson, H., (2012), Information transmission and the bullwhip effect: an empirical investigation, Management Science 58(5), pp. 860-875

Bendoly, E., Donohue, K., and Schultz, K. (2006), Behavior in operations management: assessing recent findings and revisiting old assumptions, Journal of Operations Management 24(6), pp.737-752.

Bendoly, E., Croson, R., Gonclaves, P., and Schultz, K. (2010), Bodies of knowledge for research in behavioral operations, Production and Operations Management 19(4), pp. 434-452.

Bruccoleri, M., Cannella, S. and La Porta, G. (2014), Inventory record inaccuracy in supply chains: the role of workers' behavior, International Journal of Physical Distribution \& Logistics Management 44(10), pp.1-25.

Burbidge, J.L. (1961), The New Approach to Production, Production Engineer 40(12), pp. 769-784.

Cachon, G.P (1999), Managing SC demand variability with scheduled ordering policies, Management Science 45(6), pp. 843-56.

Cachon, G.P., Randall, T. and Schmidt, G.H. (2007), In Search of the Bullwhip Effect, Manufacturing and Services Operations Management 9(4), pp. 457- 479.

Chatfield, D.C., Kim, J.G., Harrison, T.P., and Hayya, J.C. (2004), The bullwhip effect - Impact of stochastic lead time, information quality, and information sharing: a simulation study, Production and Operations Management 13(4), pp. 340-353.

Chen, F., Drezner, Z., Ryan, J.K. and Simchi-Levi. D. (2000), Quantifying the Bullwhip Effect in a Simple Supply Chain: The Impact of Forecasting, Lead Times, and Information, Management Science 46(3), pp. 436-443.

Chen, H. and Lin, T. (2009), Exploring sources of the variety in organisational innovation adoption issues - An empirical study of managers' label on knowledge management project issues in Taiwan, Expert Systems with Applications 36(2), pp. 13801390.

Chen, I.J and Paulraj, A. (2004), Towards a theory of supply chain management: the construct and measurements, Journal of Operations Management 22(2), pp. 119-50.

Chen, X., Sim, M., Simchi-Levi, D., and Sun, P. (2007), Risk aversion in inventory management, Operations Research 55(5), pp. 828-842.

Christopher, M. and Holweg, M. (2011), Supply Chain 2.0: Managing supply chains in the era of turbulence, International 
Journal of Physical Distribution \& Logistics Management 41(1), pp. 63-82.

Closs, D. J., Goldsby, T. J., and Clinton, SR. (1997), Information technology influences on world class logistics capability, International Journal of Physical Distribution \& Logistics Management 27(1), pp. 4-17.

Colyle, J. L, Gibson C.J., Novack B.J, and Bardi, E.J. (2008), Supply Chain Management: A Logistics Perspective, 8th ed., Cengage Learning, Australia

Coppini, M., Rossignoli,C., Rossi, T., and Strozzi, F. (2010), Bullwhip effect and inventory oscillations analysis using the beer game model, International Journal of Production Research 48(13), pp. 3943-3956.

Croson, R., and Donohue, K. (2006), Behavioral Causes of the Bullwhip Effect and the Observed Value of Inventory Information, Management Science 52(3), pp. 323-336

Croson, R., Donohue, K., Katok, E., and Sterman, J. (2014), Order stability in supply chains: Coordination risk and the role of coordination stock, Production and Operations Management 23(2), pp. 176-196.

Croxton, K.L., Douglas M. L., Sebastián J. G., and Dale A. R. (2006), The Demand Management Process, in Douglas M. Lambert (ed.). Supply Chain Management: Processes, Partnerships, Performance, 2 ed., Sarasota, pp. 59-76.

Data Riset Indonesia (Online), (2011), Retrieved 28 Jan 2013 from $<\mathrm{http}: / /$ datarisetindonesia.com/>

Dillman, D. (1978), Mail and Telephone surveys: The total design method, John Wiley \& Sons, Inc, New York.

Di Mauro, C., and Maffioletti, A. (2004), Attitudes to Risk and Attitudes to Uncertainty: Experimental Evidence, Applied Economics 36(4), pp. 357-372.

Disney, S.M. and Towill, D.R (2003a), On the bullwhip and inventory variance produced by an ordering policy, OMEGA 31, pp.157-67.

Disney, S.M. and Towill, D.R. (2003b), The effect of vendor managed inventory (VMI) dynamics of the bullwhip effect in supply chains, International Journal of Production Economics 85(2), pp.199-216.

Dooley, K., Yan,T., Mohan, S., and Gopalakrishnan, M. (2010), Inventory management and the bullwhip effect during the 2007-2009 recession: evidence from the manufacturing sector, Journal of Supply Chain Management 46(1),pp.12-18.

Donohue, K. and Siemsen, E. (2011), Behavioral operations: Applications in supply chain management, Wiley Encyclopedia of Operations Research and Management Science.

Evans, G.N., Naim, M.M. and Towill, D.R. (1993), Dynamic supply chain performance: assessing the impact of information systems, Logistics Information Management 6(4), pp.15-23.

Forrester, J. (1958), Industrial dynamics- a major breakthrough for decision makers, Harvard Business Review 36(4), pp. 37-66.

Forrester, J. (1961), Industrial Dynamics, MIT Press, Cambridge, MA

Geary, S., Disney, S.M. and Towill, D.R., (2006), On bullwhip in the supply chains $\sim$ historical review, present practice and expected likely impact, International Journal of Production Economics 101(1), pp. 2-18.

Gino, F. and Pisano, G (2008), Towards a theory of behavioral operations, Manufacturing and Service Operations Management 10(4), pp. 676-691.

Hsiao, J. M. M. (2006), The Impact of Retailer-supplier Cooperation and retailer-Supplier's Decision-making Uncertainty on Retail Supply Chain Performance. An unpublished PhD thesis. The University of Sydney, Australia.
Holweg, M., Disney, S., Holmstrom, J. and Smaros, J. (2005), Supply chain collaboration: making sense of the strategy continuum, European Journal of Management 23(2), pp. 170181.

Huber, G.P. and Power, D.J. (1985), Retrospective reports of strategic-level managers: guidelines for Increasing their accuracy, Strategic Management Journal 6, pp. 171-180.

Ingvaldsen, J.A. and Rolfsen, M (2012), Autonomous work groups and the challenge of inter-group coordination, Human Relations 65(7), pp. 861-881.

Kelle, P., and A. Milne, (1999), The Effect of (s, S) Ordering Policy on the Supply Chain, International Journal of Production Economics 59(1-3), pp.113-122.

Klug, F. (2013), The internal bullwhip effect in car manufacturing, International Journal of Production Research 51(1), pp. 303322.

Lau, AKW. (2015), Teaching supply chain management using a modified beer game: an action learning approach, International Journal of Logistics Research and Applications 18(1), pp. 6281.

Lee, H.L, Padmanabhan, V., and Whang, S., (1997), Information distortion in a supply chain: The bullwhip effect, Management Science 43(4), pp. 546-558.

Levy, M and Weitz, B. A. (2012), Retailing Management, 8th ed., McGraw-Hill Irwin. USA.

Li, C. and Lee, H. (2012), Bullwhip Effect Measurement and Its Implications, Operations Research 60(4), pp.771-784.

Lu, J., Humphreys, P.,McIvor, R.,Maguire, L., Wiengarten, F., (2012), Applying genetic algorithms to dampen the impact of price fluctuations in a supply chain, International Journal of Production Research 50(19), pp.5396-5414.

Ma, Y., Wang, N., Che, A., Huang, Y., Xu, J. (2013). The bullwhip effect on product orders and inventory: a perspective of demand forecasting techniques, International Journal of Production Research 51(1), pp. 281-302

Machuca, J.A. and Barajas, R.P., (2004), The impact of electronic data interchange on reducing bullwhip effect and supply chain inventory costs, Transportation Research Part E, Logistics \& Transportation Review 40E(3), pp. 209-228.

Martín, V.E. (2008), Technology Gap among Suppliers and Pop \& Mom Stores as a Key Distribution Cost Issue, PICMET, Proceedings, 27-31 July, Cape Town, South Africa.

Mauro, C., and Maffioletti, A. (2004), Attitudes to risk and attitudes to uncertainty: experimental evidence, Applied Economics 36(4), pp.357-372.

McCullen, P. and Towill, D. (2002), Diagnosis and Reduction of Bullwhip in Supply Chains, Supply Chain Management: An International Journal 7(3), pp.164-79.

Metter, R, (1997), Quantifying the Bullwhip effect in supply chains, Journal of Operations Management 15(2), pp.89-100.

Miragliotta, G., (2006), Layers and Mechanisms: A New Taxonomy for the Bullwhip Effect, International Journal of Production Economics 104(2), pp. 365-381

NAICS. North American Industry Classification System (NAICS), (2012), http://www.census.gov/eos/www/naics/: United States Cencus Bereau.

Nielsen, E.H. (2013), Small sample uncertainty aspects in relation to bullwhip effect measurement, International Journal of Production Economics 146(2), pp.543-549.

Nienhaus, J., Ziegenbein,A., Duijts, C. (2002), How human behaviour amplifies the bullwhip effect - a study based on the beer distribution game online, Supply Chain World Europe, pp.28-30. 
O’Donnell, T., Maguire, L., McIvor, R. and Humphreys, P. (2006), Minimising the bullwhip effect in a supply chain using genetic algorithms, International Journal of Production Research 44(8), pp. 1523-1543.

Ouyang, Y., and Li, Xiaopeng, (2010), The Bullwhip Effect in Supply Chain networks, European Journal of Operational Research 201, pp. 799-810.

Paik, S., and Bagchi, P.K. (2007), Understanding the causes of the bullwhip effect in a supply chain", International Journal of Retail \& Distribution Management 35(4), pp. 308-324.

Pujawan, I.N. and Silver E.A. (2008), Augmenting the lot sizing order quantity when demand is probabilistic, European Journal of Operational Research 188(2), pp. 705-722.

Robertson, G. L. (2006), Food Packaging Principles and Practice (2nd edition ed.). Boca Raton, CRC Press, Florida.

Robertson, G. L. Food Packaging and Shelf Life. In G. L. Robertson (Ed.),(2010), Food Packaging and Shelf Life: A Practical Guide, CRC Press Taylor \& Francis Group, New York.

Santhanam, R., and Hartono, E. (2003), Issues in linking information technology capability to firm performance, MIS Quarterly 27(1), pp. 125-153.

Shan, J., Yang, S., Yang, S., Zhang, J. (2014), An empirical study of the bullwhip effect in China, Production \& Operations Management 23(4), pp.537-55.

Silver, E.A., Pyke, D.F., Peterson, R., (1998). Inventory Management and Production Planning and Scheduling, Third Edition ed. John Wiley \& Sons.

Simchi-Levi, D., Kaminsky, P. and Simchi-Levi, E., (2000), Designing and Managing the Supply Chain. Concepts, Strategies, and Case Studies, Irwin McGraw-Hill: New York.

Simon, H. (1979). Rational decision making in business organizations, American Economic Review 69(4), pp. 493-513.

Sterman, JD (1989), Modeling managerial behavior, misperception of feedback in a dynamic decision-making environment, Management Science 35 (3), pp. 21-99.

Sundarakani, B., Tan, A. and Van Over, D. (2012), Enhancing the supply chain management performance using information technology: some evidence from UAE companies, International Journal of Logistics Systems and Management 11(3), pp. 306-324.

Tarikere T. N., Wagnera, SM and Aggarwal, V. (2011), Measuring information distortion in real-world supply chains, International Journal of Production Research 49(11), pp.3343-3362

Taylor, D.H. (1999), Measurement and analysis of demand amplification across the supply chain, International Journal of Logistics Management 10(2), pp.55-70.
Taylor, D.H. (2000), Demand Amplification: Has it got us beat?, International Journal of Physical Distribution and Logistics Management 30(6), pp. 515-533.

Taylor, DH and Fearne, A. (2006), Towards a framework for improvement in the management of demand in agri-food supply chains, Supply Chain Management: An International Journal 11(5), pp. 379-384.

Taylor, DH. and Fearne, A. (2009), Demand Management in Fresh Food Value Chains: A Framework for Analysis and Improvement, Supply Chain Management: An International Journal 14(5), pp. 379-392.

Tiwari, V. and Gavirneni, S., (2007), The Art and Science of Practice: Recoupling Inventory Control Research and Practice: Guidelines for Achieving Synergy, Interfaces 37(2), pp. 176186.

Torres, O.C. and Maltz, A.B. (2010), Understanding the financial consequences of the Bullwhip effect in a multi-echelon supply chain, Journal of Business Logistics 31(1), pp.23-41.

Towill, D.R. (1991), Supply chain dynamics, International Journal of Computer Integrated Manufacturing 4(3), pp.197-208.

Towill, D.R. and McCullen, P. (1999), The impact of agile manufacturing on supply chain dynamics, International Journal of Logistics Management 10(1), pp. 83-96.

Van Donselaar, K., Gaur, V., Van Woensel, T., Broekmeulen, R.A.C.M., and Fransoo, J.C., (2010), Ordering Behavior in Retail Stores and Implications for Automated Ordering, Management Science 56(5), pp.766-784.

Van Zelst, S., Van Donselaar K., Van Woensel, T., R., and Broekmeulen, J.F. (2009), Logistics drivers for shelf stacking in grocery retail stores: Potential for efficiency improvement, International Journal of Production Economics 121(2), pp. 620-632.

Van der Vorst, J. (2000), Effective Food Supply Chains: Generating, modeling and evaluating supply chain scenarios, An unpublished PhD-thesis. Wageningen University, The Netherlands.

Van der Vorst, J. and Beulens, A. (2002), Identifying sources of uncertainty to generate supply chain redesign strategies, International Journal of Physical Distribution \& Logistics Management 32(6), pp. 409-430.

Warburton, R. D. H., (2004), An Analytical Investigation of the Bullwhip Effect, Production and Operations Management 13(2), pp. 150-160.

Zotteri, G. (2013), An empirical investigation on causes and effects of the Bullwhip-effect: Evidence from the personal care sector, International Journal of Production Economics 143(2), pp. 489-498.

Dr. Himanshu Shee is currently a Senior Lecturer at Victoria University specialising in operations and supply chain management as well as SAP-APO optimisation module. He has a successful teaching career across Australia, China, Singapore, Kuala Lumpur, Fiji and India. With a good track record in research, publications and higher degree research supervision he has published in many peer-reviewed journals like Int. Journal of Logistics: research \& applications, IIMB Management Review, International Journal of Global Business and Competitiveness, Journal of Management \& Organization, Journal of Transnational Management and Asian Academy of Management Journal. Many prestigious conferences like POMS, EUROMA, Academy of Management, ANZAM-OM and IS-DSI India where he presented his research. Further, he authored a book on Firm Competitiveness: Case of software firms. His supervision of many $\mathrm{PhD} \& \mathrm{DBA}$ research scholars includes sustainable supply chain, demand management, logistics outsourcing, buyer-supplier relationship and Australian automotive import supply chain management. Dr Shee has been appointed as Associate editor for International Journal of Global Business and Competitiveness (IJGBC) and a regular reviewer for many reputed journals. Recently he is appointed as a Board member in IS-DSI India conference for 2016. 
Dr. Surahman Kaswi has a PhD from Victoria University Melbourne in Supply Chain Management. His research interests include broad areas of supply chain and logistics management, and retail marketing. He has a successful teaching career at Politeknik Negeri Samarinda and Mulawarman University in Indonesia. Many prestigious conferences like ANZAM-OM and Operations and Supply Chain Management where he presented his research. Further he authored a book on Retail Marketing. Recently Surahman works as a lecturer and researcher at Politeknik Negeri Samarinda in Indonesia, where he conducts research on retail marketing, efficiencies improvement in chain operations and retail supply chain in Indonesia and ASEAN region. 